\title{
Serum Granulysin in Differentiation of Stevens-Johnson Syndrome/toxic Epidermal Necrolysis and Erythema Multiforme
}

\author{
Tran Thi Huyen ${ }^{1,2 \star}$, Pham Dinh Hoa ${ }^{1,2}$, Trinh Minh Trang ${ }^{2}$, Riichiro Abe ${ }^{3}$, Nguyen Van Thuong $^{1,2}$, Pham Thi Lan $^{1,2}$, Michael Tirant $^{1}$ \\ ${ }^{1}$ Department of Dermatology and Venereology, Hanoi Medical University, Hanoi, Vietnam; ${ }^{2}$ Department of Skin Diseases of \\ Women and Children, National Hospital of Dermatology and Venereology, Hanoi, Vietnam; ${ }^{3}$ Department of Dermatology, \\ Niigata University, Japan
}

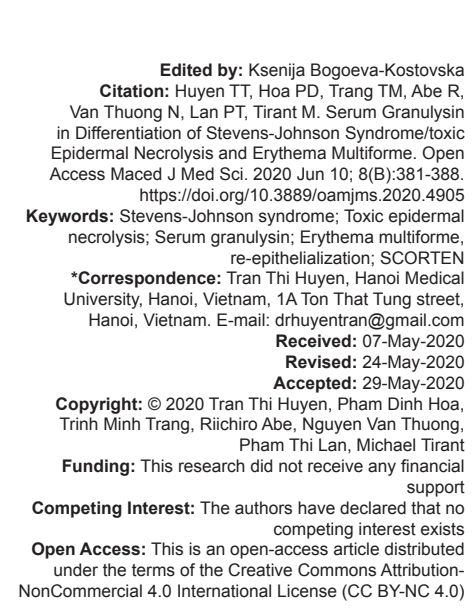

\section{Introduction}

Stevens-Johnson syndrome (SJS) and toxic epidermal necrolysis (TEN) are severe cutaneous adverse drug reactions (SCARs) characterized by extensive epidermal necrolysis, blisters, and skin sloughing [1], [2]. The most common causative drugs of SJS/TEN are carbamazepine, allopurinol, abacavir, phenytoin, and lamotrigine [1], [3], [4], [5]. The period between taking a drug and onset of symptoms ranges from a few days to 2 months [1], [2], [6]. SJS and TEN are categorized based on the percentage of epidermal detachment area: (i) SJS: $<10 \%$, (ii) TEN: $>30 \%$, and (iii) overlapping SJS/TEN: 10-30\% [2].

The pathogenesis of SJS/TEN is not fully understood, but there are some immunological and genetic factors which are believed to be involved [4], [5], [7], [8], [9]. There is a strong association between $H L A-B^{*} 15: 02$ and carbamazepine-induced SJS/TEN [10], [11], [12], HLA-B*58:01 and allopurinolinduced SJS/TEN [13], [14], [15], and $H L A-B * 57: 01$ and abacavir-induced SJS/TEN [15], [16], [17]. CD8+ cytotoxic
T cells (CTLs) and natural killer (NK) cells play an important role in the pathogenesis of SJS/TEN [1], [4], [5], [8], [9]. The immune response may be triggered by binding an antigenic drug to a specific HLA on a keratinocyte [4], [5]. Specific T cell receptors recognize the drug-HLA complex and upon the activation, CD8+CTLs and NK cells produce cytokines, chemokines, and cytotoxic proteins, particularly granulysin, that cause extensive keratinocytes apoptosis [4], [5]. Chung reported that granulysin concentrations in the blister fluid of SJS/TEN patients were 2-4 times higher than perforin, granzyme B, or soluble Fas ligand concentrations [18]. Granulysin in the blister fluid was $15-k D a$ secretory form, and injection of it into mouse skin resulted in features mimicking SJS/TEN [5], [18], [19]. Abe showed that serum granulysin levels in patients with SJS/TEN were elevated before skin detachment or mucosal lesions developed [20]. The rapid immunochromatographic test has been developed for serum granulysin to diagnose early SJS/TEN [21].

Erythema multiforme (EM) may have skin manifestation similar to SJS/TEN [2], [22], [23], but they can be distinguished immunopathologically. In cases of SJS/TEN, the inflammatory infiltrates expressing 
granulysin, granzyme B, and perforin accumulated predominantly in the lower epidermal and subepidermal bulla, in contrast, they were relatively sparse in EM [24]. However, this test is not clinically rapid. On the other hand, serum granulysin levels may be elevated among SJS/TEN patients [20], [25]. To the best of our knowledge, there is no study compared serum granulysin levels in SJS/TEN with those in EM. We conducted this study to investigate serum granulysin levels in patients with SJS/TEN and EM as well as possible associations between serum granulysin levels and the severity of SJS/TEN.

\section{Materials and Methods}

\section{Participants}

\section{SJS/TEN patients}

In total, 48 patients with SJS/TEN were enrolled from January 2018 to October 2019 at two hospitals in Hanoi, Vietnam (National Hospital of Dermatovenereology and Bach Mai Hospital). The SJS/TEN patients had their vital signs and systemic symptoms and the percentage of body surface area affected (skin detachment) examined. SJS and TEN were classified in accordance with Bastuji-Garin et al. [2]. All patients were aged 18 or older. The onset was defined as the day mucocutaneous or ocular lesions were first eroded or ulcerated [20]; the re-epithelialization was defined as complete healing of the skin without any erosion [26]. The severity of SJS/TEN patients was also assessed by the modified-SCORTEN (SCORe of TEN) scale that was composed of six well-defined criteria, including age $>40$ years, malignancy, tachycardia $>120$ beats $/ \mathrm{min}$, percentage of epidermal detachment $>10 \%$, serum urea $>10 \mathrm{mmol} / \mathrm{L}$, and serum glucose $>14 \mathrm{mmol} / \mathrm{L}$. This scale was based on SCORTEN scale of Bastuji-Garin et al. consisting of seven criteria [27].

\section{EM patients and health controls (HCs)}

There were 43 patients with EM recruited in this study. They had the presence of typical or atypical cutaneous target lesions, with or without mucous membrane lesions. The causes of EM were either drugs or unknown. Twenty HCs recruited were healthy medical staff in the National Hospital of Dermatology and Venereology, Ha Noi, Vietnam.

\section{Measuring serum granulysin levels}

In the SJS/TEN group, we took blood samples at 2-time points (1) at the day of hospitalization and (2) at the day of re-epithelialization. In the EM group, blood samples were taken at the day of hospitalization.
All blood samples were left to coagulate at room temperature 10-20 min, then centrifuged in $20 \mathrm{~min}$ at a speed of 2000-000 r.p.m, finally serum was taken and stored at $-20^{\circ} \mathrm{C}$ until proceeding the granulysin measurement.

Using enzyme-linked immunosorbent assay (ELISA) (Human Granulysin ELISA Kit, MELSIN, China), we quantified granulysin in all serum samples. The kit used ELISA-double antibody sandwich principle to assess granulysin levels. The microELISA strip plate provided in this kit has been coated by purified granulysin antibody to make solid-phase antibody, in sequence granulysin is added to wells, combined with granulysin antibody labeled by horseradish peroxidase, which then becomes an antibody-antigen-enzymeantibody complex. After washing completely to remove the uncombined enzyme, chromogen solution $A$ and chromogen solution $\mathrm{B}$ were added, changing the color of the liquid to blue which in turn turns into yellow due to the effect of acid. The color change was measured spectrophotometrically at a wavelength of $450 \mathrm{~nm}$. The concentration of granulysin in the samples was then determined by comparing the O.D. of the samples to the standard curve. The minimum detectable dose of granulysin is typically $<0.15 \mathrm{ng} / \mathrm{ml}$ (following manufacturer's instruction).

\section{Statistical analysis and ethical clearance}

Data entry and analysis were conducted by using SPSS software version 16.0 (IBM, Armonk, NY, USA). The Mann-Whitney $U$ test and Wilcoxon test were used to compare quantitative variables. Differences were considered to be statistically significant at $p<0.05$.

The study was approved by the Ethical Review Committee on Research Involving Human Subjects, Hanoi Medical University (Number 04NCS17, dated February 08, 2018). Written consent was obtained from all participants.

\section{Results}

There were 19 SJS patients (39.5\%) and 29 TEN patients $(60.5 \%)$ participating in our study. Their characteristics are shown in Table 1. The mean age was 49.3 , range $19-77$ years $(47.9 \%$ males; $52.1 \%$ females). The most common causative drugs were traditional medicine $(29.1 \%)$, carbamazepine $(12.5 \%)$, and allopurinol $(12.5 \%)$. The time between the onset and the day of hospitalization was $5.9 \pm 2.7$ days (range $2-18$ days). The mean body surface area affected was $43.7 \%$. The mean m-SCORTEN score was 1.6. The mean time of re-epithelialization was 15.9 days (range 9-31 days). All SJS/TEN patients got re-epithelialization and total resolution, no one with in-hospital mortality. 
The characteristics of EM patients are shown in Table 2. The mean age was 41.4, range 19-76 (30.2\% males; $69.8 \%$ females). The medication was responsible for $41.9 \%$ of patients with EM.

Table 1: Characteristics of patients with SJS/TEN

\begin{tabular}{|c|c|c|c|}
\hline Characteristics & SJS $(n=19)$ & TEN $(n=29)$ & SJS/TEN $(n=48)$ \\
\hline Age, years & $44.9 \pm 15.3$ & $52.2 \pm 14.3$ & $49.3 \pm 15.0$ \\
\hline (Range) & $(19-72)$ & $(25-77)$ & $(19-77)$ \\
\hline \multicolumn{4}{|l|}{ Sex, n (\%) } \\
\hline Male & $11(57.9)$ & $12(41.4)$ & $23(47.9)$ \\
\hline Female & $8(42.1)$ & $17(58.6)$ & $25(52.1)$ \\
\hline \multicolumn{4}{|l|}{ Causative drugs, $\mathrm{n}(\%)$} \\
\hline Carbamazepine & $5(26.2)$ & $1(3.4)$ & $6(12.5)$ \\
\hline Allopurinol & $4(21.1)$ & $2(6.9)$ & $6(12.5)$ \\
\hline Traditional medicine & $2(10.5)$ & $12(41.5)$ & $14(29.1)$ \\
\hline Antibiotics & $1(5.3)$ & $2(6.9)$ & $3(6.2)$ \\
\hline NSAIDs & $1(5.3)$ & $3(10.3)$ & $4(8.4)$ \\
\hline Thalidomide & $0(0)$ & $1(3.4)$ & $1(2.1)$ \\
\hline Unknown & $6(31.6)$ & $8(27.6)$ & $14(29.2)$ \\
\hline $\begin{array}{l}\text { The time between onset and } \\
\text { hospitalization, days }\end{array}$ & $5.5 \pm 1.6$ & $6.1 \pm 3.2$ & $5.9 \pm 2.7$ \\
\hline \multicolumn{4}{|c|}{ Taking corticosteroids before hospitalization, $\mathrm{n}(\%)$} \\
\hline Yes & $7(36.8)$ & $13(44.8)$ & $20(41.7)$ \\
\hline No & $8(42.1)$ & $13(44.8)$ & $21(43.7)$ \\
\hline Unknown & $4(21.1)$ & $3(10.4)$ & $7(14.6)$ \\
\hline Body surface area affected, \% & $7 \pm 7.4$ & $67.8 \pm 21.7$ & $43.7 \pm 34.7$ \\
\hline m-SCORTEN score & $1 \pm 0.9$ & $2 \pm 0.7$ & $1.6 \pm 0.9$ \\
\hline Fever, n (\%) & $8(42.1)$ & $19(65.5)$ & $27(56.2)$ \\
\hline High levels of liver enzymes, $n(\%)$ & $11(57.9)$ & $19(65.5)$ & $30(62.5)$ \\
\hline Malfunction of kidney & $6(31.6)$ & $14(48.3)$ & $20(41.7)$ \\
\hline Mucous membrane lesions & $18(94.7)$ & $21(72.4)$ & $39(81.2)$ \\
\hline Pneumonia & $0(0)$ & $8(27.6)$ & $8(16.7)$ \\
\hline \multicolumn{4}{|c|}{ Treatment given during hospitalization, $\mathrm{n}(\%)$} \\
\hline Systemic corticoid & $16(84.2)$ & $19(65.5)$ & 35 (72.9) \\
\hline Ciclosporin A & $3(15.8)$ & $8(27.6)$ & $11(22.9)$ \\
\hline Only care support & $0(0)$ & $2(6.9)$ & $2(4.2)$ \\
\hline $\begin{array}{l}\text { The time of re-epithelialization, days } \\
\text { (Range) }\end{array}$ & $\begin{array}{l}13.8 \pm 3.7 \\
(9-23)\end{array}$ & $\begin{array}{l}17.2 \pm 4.6 \\
(10-31)\end{array}$ & $\begin{array}{l}15.9 \pm 4.6 \\
(9-31)\end{array}$ \\
\hline
\end{tabular}

Table 2: Characteristics of patients with EM and HCs

\begin{tabular}{lll}
\hline Characteristics & EM $(\mathrm{n}=43)$ & $\mathrm{HCs}(\mathrm{n}=20)$ \\
\hline $\begin{array}{l}\text { Age, years } \\
\text { (range) }\end{array}$ & $41.4 \pm 17.3$ & $28.4 \pm 3.5$ \\
Sex, $\mathrm{n}(\%)$ & $(19-76)$ & $(25-37)$ \\
$\quad$ Male & $13(30.2)$ & $10(50)$ \\
$\quad$ Female & $30(69.8)$ & $10(50)$ \\
Causes, $\mathrm{n}(\%)$ & & $\mathrm{NA}$ \\
$\quad$ Medication & $18(41.9)$ & \\
Traditional medicine & $8(44.4)$ & \\
Antibiotics & $5(27.8)$ & \\
Allopurinol & $3(16.6)$ & \\
Herbal food & $2(11.2)$ & \\
Unknown & $25(58.1)$ & \\
Cutaneous lesions, $\mathrm{n}(\%)$ & & \\
$\quad$ Typical targets & $7(16.3)$ & \\
Atypical targets & $30(69.7)$ & $\mathrm{NA}$ \\
Both typical and atypical targets & $6(14)$ & $\mathrm{NA}$ \\
Mucous membrane lesion, $\mathrm{n}(\%)$ & $9(20.9)$ & \\
Fever, $\mathrm{n}(\%)$ & $10(23.3)$ & \\
\hline
\end{tabular}

Serum granulysin levels of patients with SJS/TEN (23.0 ng/ml; range 1.2-144.6 ng/ml) were significantly higher than those of patients with EM (20.1 $\mathrm{ng} / \mathrm{ml}$; range $8.5-121 \mathrm{ng} / \mathrm{ml} ; \mathrm{p}<0.05)$ and those of $\mathrm{HCs}$ (20.8 ng/ml; range 10.1-46.7 ng/ml; $\mathrm{p}<0.05)$ (Figure 1). There was no significant difference with regard to serum granulysin levels among SJS and TEN patients (21.7 $\mathrm{ng} / \mathrm{ml}$ versus $23.9 \mathrm{ng} / \mathrm{ml}$; $\mathrm{p}>0.05$ ) (Figure $2 \mathrm{a}$ ). In the SJS/TEN group, serum granulysin levels were higher in the 25 samples collected $<6$ days of the onset $(27.7$ $\mathrm{ng} / \mathrm{ml}$; range $2.5-144.6 \mathrm{ng} / \mathrm{ml}$ ) than in the 23 samples collected $\geq 6$ days after the onset $(17.9 \mathrm{ng} / \mathrm{ml}$; range $1.2-59 \mathrm{ng} / \mathrm{ml}$ ) but it was not significantly different $(p>0.05)$ (Figure $2 b)$. Serum granulysin levels were not significantly different between male and female patients with SJS/TEN (Figure 2c). In patients with SJS/ TEN, there was a negative correlation between serum granulysin levels and the ages with $r=(-0.25)$, but it was not statistically significant $(p=0.081)$ (Figure $3 a)$. There was no correlation between serum granulysin levels and the body surface area affected $(r=0.12 ; p=0.417)$ (Figure 3b); between serum granulysin levels and modified-SCORTEN with $r=(-0.16), p=0.29$ (Figure $3 c$ ). Serum granulysin levels were not affected by some clinical/paraclinical such as fever, malfunction of kidney, pneumonia, high level of liver enzymes, and mucous membrane lesion (Figure 4). We had a TEN patient whose progress of disease is shown in Figure 5.

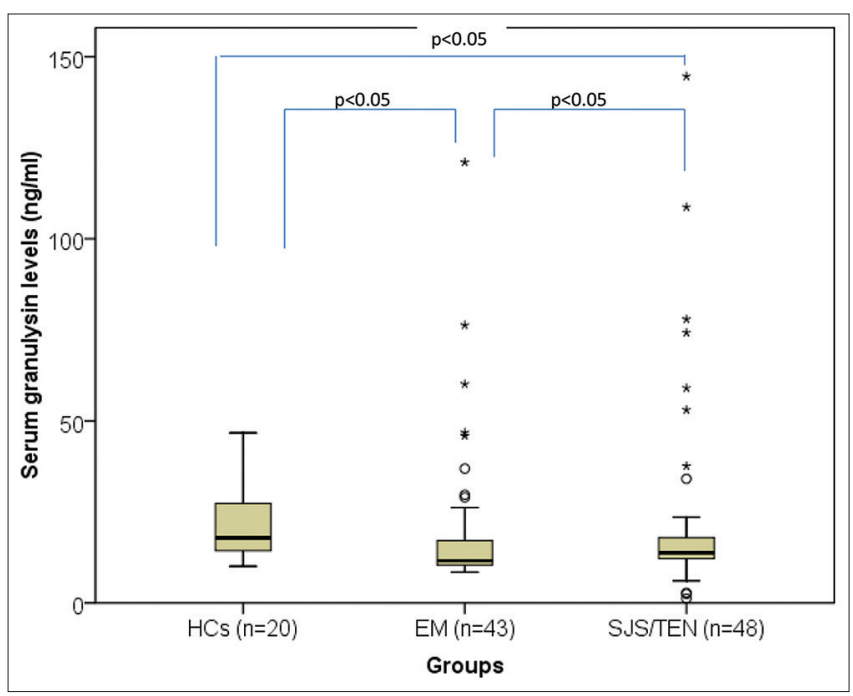

Figure 1: Serum granulysin levels of healthy controls, erythema multiforme group, and Stevens-Johnson syndrome/toxic epidermal necrolysis $p>0.05$ group

\section{Discussion}

This study showed that serum granulysin levels in SJS/TEN patients were statistically higher than those in EM patients. There was no significant difference with regard to serum granulysin levels in SJS and TEN patients. Serum granulysin levels in patients hospitalized $<6$ days of the onset were higher than after $\geq 6$ days; however, it was not statistically significant.

Granulysin is a cytolytic molecule presenting in human CTL and NK cell granules [28] and is lytic against a variety of tumor cell targets and microbes [28], [29]. In combination with purified perforin, recombinant granulysin breaks up $90 \%$ of intracellular Mycobacterium tuberculosis, inducing lesions on the mycobacterial cell surface [29]. Previous studies as regards SJS/TEN support the concept that SJS/TEN are SCARs initiated by CTLs [5], [8], [18], [30]. It has been observed that in patients with SJS/TEN, CTLs, and NK cells infiltrate the skin lesions, which point to cutaneous recruitment of antigen-primed CTLs in the pathogenesis of SJS/TEN [8], [18], [31]. Chung demonstrated that SJS/TEN blister cells were, in most part, formed by CD8+CTLs, CD56+NK, and NK cells, 

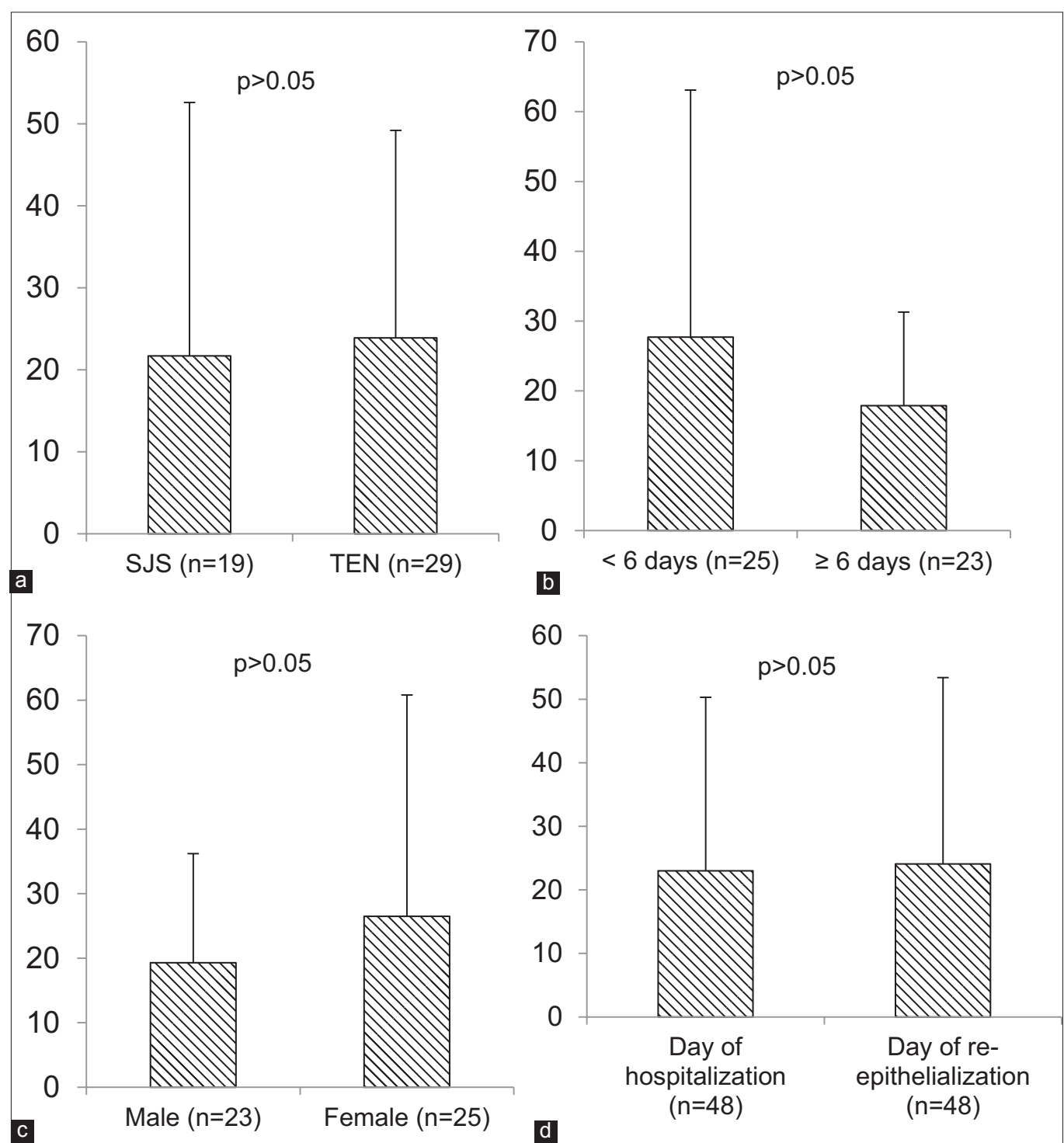

Figure 2: Comparison of serum granulysin levels ( $\mathrm{ng} / \mathrm{ml}$ ) in SJS/TEN: Between SJS and TEN (a); the 25 samples collected $<6$ days of the onset and the 23 samples collected $\geq 6$ days after the onset (b); male and female patients (c); At the day of hospitalization and re-epithelialization (d). SJS: Stevens-Johnson syndrome; TEN: toxic epidermal necrolysis

and these effector cells showed cytotoxicity against target cells [18]. These findings are favorable to the key role of granulysin, a product of CTLs and NK cells, in the pathogenesis of SJS/TEN.

EM is a cutaneous reaction characterized by typical or atypical target lesions that mimic cutaneous manifestations of SJS/TEN in the early phase [2], [22], [23]. The causes of EM may be a viral infection or drug reaction [22], [23], [32]. Serum granulysin can be also elevated in viral infected conditions [33] such as virus-associated EM. Nevertheless, our results may imply the use of serum granulysin as a biomarker for distinguishing between EM and SJS/TEN. In fact, serum granulysin levels can be affected by some factors such as infection [33], [34], [35], sepsis [36], cancers [34], [37], age [33], and immunological condition [35], hence, it was a large range among our SJS/ TEN patients. However, systemic corticosteroid treatment before hospitalization did not affect serum granulysin levels in patients with SJS/TEN.
In the present study, there was no association between serum granulysin levels and some clinical/ paraclinical manifestations of SJS/TEN. At the day of re-epithelialization, serum granulysin levels were not significantly different compared with those at the day of being hospitalized. These findings could be explained by the fact that nearly all the 48 patients with SJS/TEN in this study had their serum granulysin measured after the onset (mean 5.9 days) when serum granulysin levels could be decreased. Abe et al. showed that in SJS/TEN, serum granulysin levels were elevated before the onset (when skin detachment or mucosal lesion develop) and higher than those of ordinary drug-induced skin reactions [20]. However, the mean level of serum granulysin in this study was consistent with that in Abe's et al. study $(24.8 \mathrm{ng} / \mathrm{ml})$ [20]. It could be due to the difference in the size of samples in each study.

By using the sandwich ELISA method, a study in Japan shows the mean level of serum granulysin among 

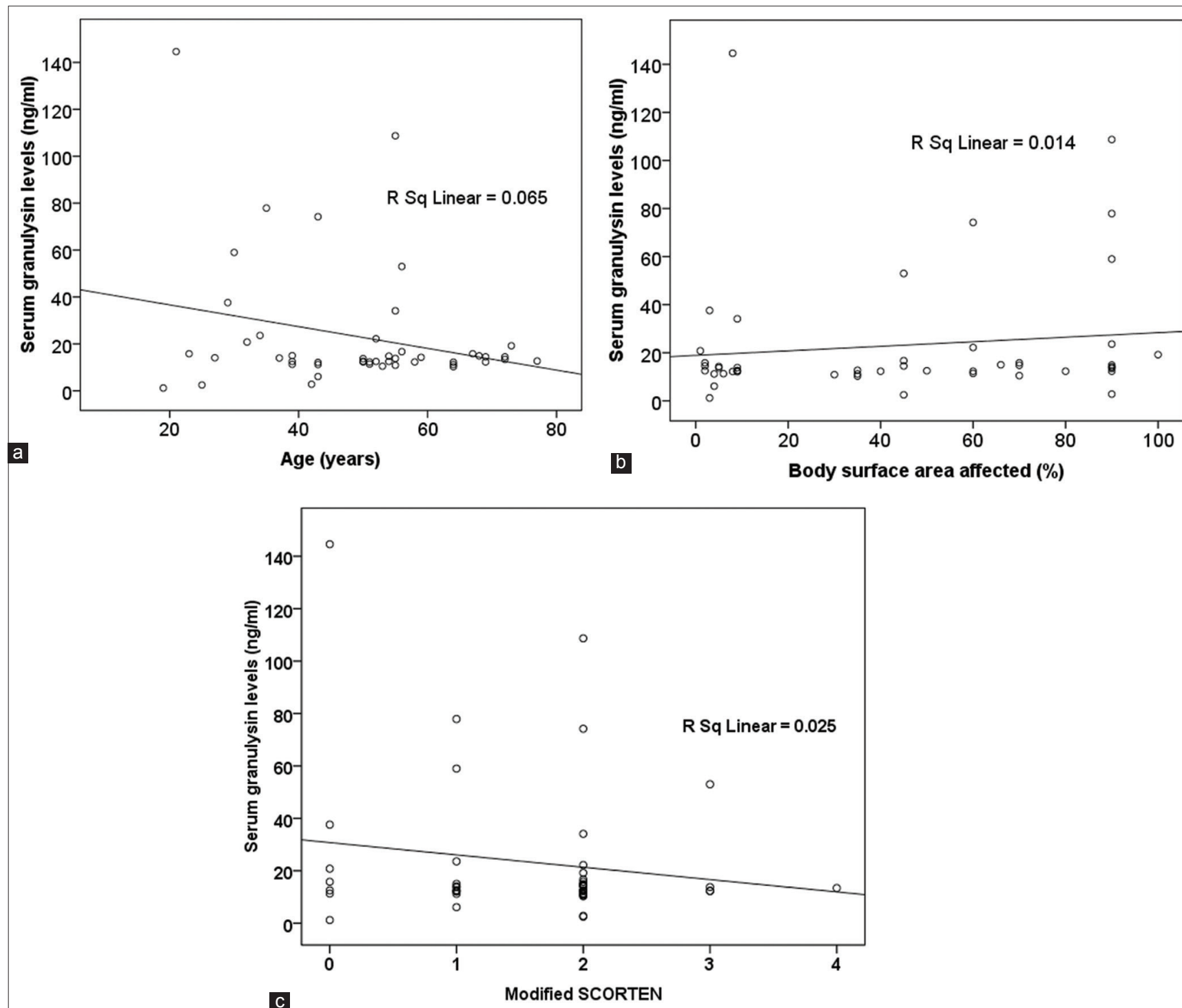

Figure 3: Correlation between serum granulysin levels in SJS/TEN patients and the ages (a), the body surface area affected (b), the modifiedSCORTEN (c). SJS: Stevens-Johnson syndrome; TEN: Toxic epidermal necrolysis; SCORTEN: SCORe of toxic epidermal necrolysis

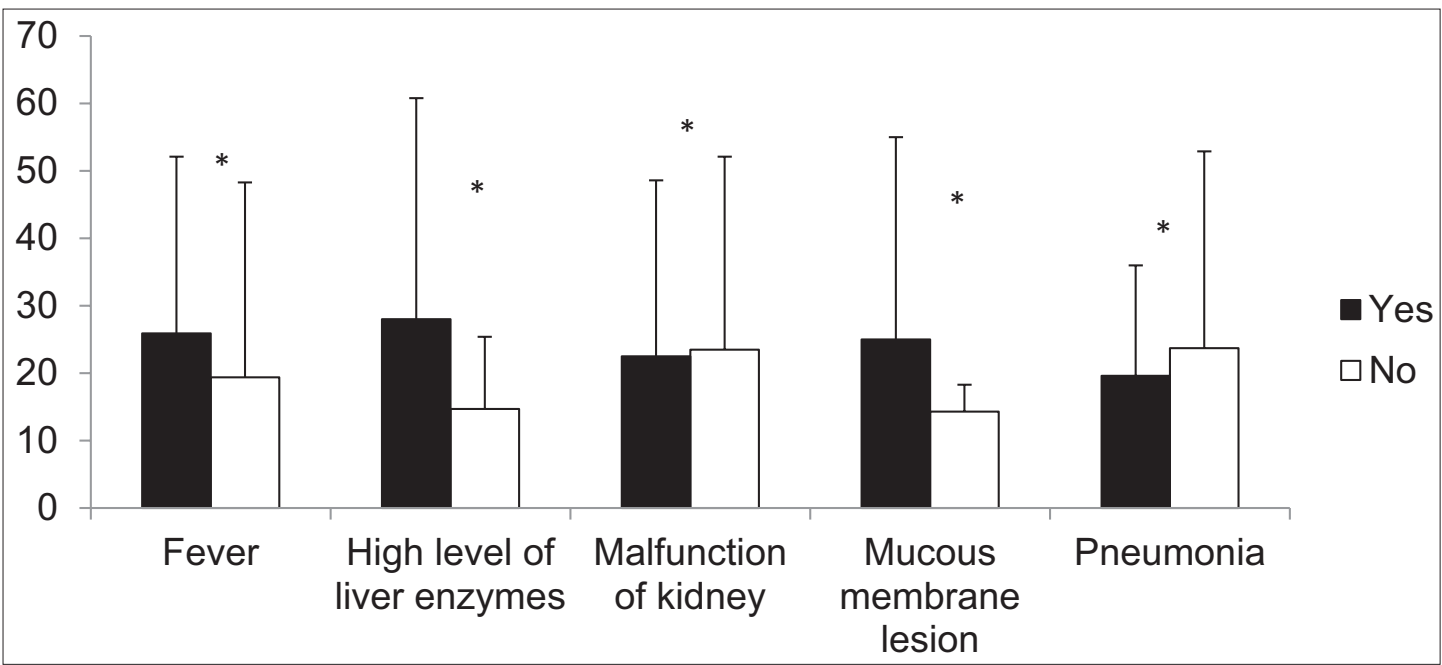

Figure 4: Serum granulysin levels $(\mathrm{ng} / \mathrm{ml})$ and some clinical/paraclinical in patients with SJS/TEN; ${ }^{*} p>0.05$. SJS: Stevens-Johnson syndrome; TEN: Toxic epidermal necrolysis

healthy individuals is $3.7 \mathrm{ng} / \mathrm{ml}$, and it also demonstrates a positive correlation between serum granulysin levels and age, but no significant difference in serum granulysin levels between genders [33]. Furthermore, 


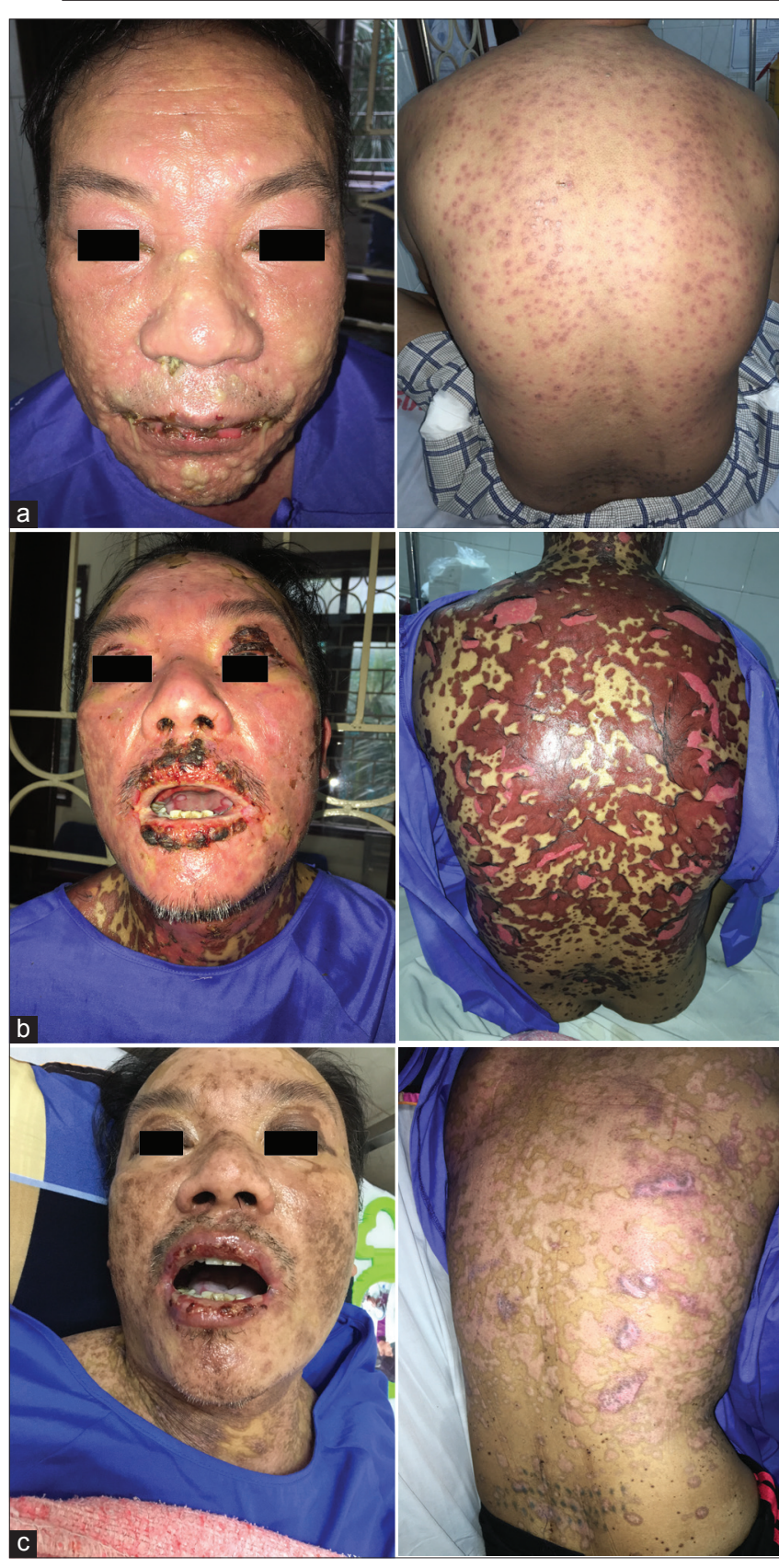

Figure 5: A 52-year-old male patient with allopurinol-induced toxic epidermal necrolysis and serum granulysin level results. (a) At the day of hospitalization: Serum granulysin level was $22.2 \mathrm{ng} / \mathrm{ml}$, (b) ten days after hospitalization, extensive necrolysis of skin, (c) at the day of re-epithelialization: Serum granulysin level was $17.1 \mathrm{ng} / \mathrm{ml}$

a study among health staffs from tuberculosis hospitals in Hanoi, Vietnam, also shows lower levels of serum granulysin as compared with those of the present study [35]. This may be due to the difference in study populations, age, and immunological conditions. On the other hand, HCs in our study were medical staff, who possibly have higher chances of being exposed to bacterial or viral infections in hospital environments.

Cho et al. showed that the serum level of granulysin of patients with generalized bullous fixed drug eruption (GBFDE) was significantly lower than that of patients with SJS/TEN overlap or TEN [25]. In GBFDE, granulysin is mainly produced by NK cells, whilst in SJS/TEN both NK cells and CTLs play an essential role. The presence of granulysin in lesional skin and in serum is a principal factor to distinguish GBFDE from SJS/TEN [25]. Furthermore, serum granulysin levels are not elevated exclusively in SJS/TEN; other conditions have also shown to be responsible for high serum granulysin levels, such as graft-versus-host disease [33], [38], drug reaction with eosinophilia and systemic symptoms, or druginduced hypersensitivity syndrome [39]. Another study in Taiwan shows that high plasma granulysin levels were associated with renal impairment and mortality rates of patients with allopurinol-induced SJS/TEN [14]. Deceased patients showed higher concentrations of granulysin for extended periods of time when compared to the survivors [14]. Su et al. demonstrated that the levels of interleukin-15 and granulysin were significantly correlated with the disease extension in SJS/TEN [36]. These studies implied that serum granulysin levels may be used as a biomarker for not only the diagnosis but also the prognosis of SCARs. However, in our study, after the onset of SJS/TEN, serum granulysin level is not useful for evaluating the severity of SJS/TEN.

This study had some limitations. First, we collected serum samples several days after the onset of SJS/TEN when serum granulysin levels might have been decreased a lot. Second, HCs group were healthy health staffs whose serum granulysin levels might be higher than those of the general population. Third, we only measured granulysin levels in sera and were not able to quantify them in blister fluids and identify the presence of granulysin on skin tissue. Fourth, we did not identify the cells secreting granulysin. In fact, there are other cytotoxic proteins and molecules such as perforin, granzyme B [5], [18], [40], and annexin $A 1$ [41] relating to the pathogenesis of SJS/ TEN but we could not investigate all of them. Finally, we used modified-SCORTEN as serum bicarbonate test was not available in the study settings. However, the mean $\mathrm{m}$-SCORTEN in this study was consistent with the mean SCORTEN of a previous study in Vietnam [11].

\section{Conclusion}

Serum granulysin levels are significantly higher in SJS/TEN patients than in EM patients. After the onset of SJS/TEN, serum granulysin is not associated with the severity of the diseases.

\section{References}

1. Schwartz RA, McDonough PH, Lee BW. Toxic epidermal necrolysis: Part I. Introduction, history, classification, 
clinical features, systemic manifestations, etiology, and immunopathogenesis. J Am Acad Dermatol 2013;69(2):173. e1-13; quiz 185-6.

\section{PMid:23866878}

2. Bastuji-Garin S, Rzany B, Stern RS, Shear NH, Naldi L, Roujeau JC. Clinical classification of cases of toxic epidermal necrolysis, Stevens-Johnson syndrome, and erythema multiforme. Arch Dermatol 1993;129(1):92-6. https://doi. org/10.1001/archderm.129.1.92

3. Sassolas B, Haddad C, Mockenhaupt M. ALDEN, an algorthm for assessment of drug causality in Stevens-Johnson syndrome and toxic epidermal necrolysis: Compatison with case-control analysis. Clin Pharmacol Ther 2010;88(01):60-8. https://doi. org/10.1038/clpt.2009.252

PMid:20375998

4. Chung WH, Wang CW, Dao RL. Severe cutaneous adverse drug reactions. J Dermatol 2016;43(7):758-66. https://doi. org/10.1111/1346-8138.13430

PMid:27154258

5. Su SC, Chung WH. Cytotoxic proteins and therapeutic targets in severe cutaneous adverse reactions. Toxins 2014;6(1):194-210. https://doi.org/10.3390/toxins6010194

PMid:24394640

6. Creamer D, Walsh SA, Dziewulski P, Exton LS, Lee HY, Dart JK, et al. U.K. guidelines for the management of StevensJohnson syndrome/toxic epidermal necrolysis in adults 2016 . Br J Dermatol 2016;174:1194-227. https://doi.org/10.1016/j. jaci.2010.11.048

PMid:27216885

7. Pichler WJ, Naisbitt DJ, Park BK. Immune pathomechanism of drug hypersensitivity reactions. J Allergy Clin Immunol 2011;127(3 Suppl):S74-81.

PMid:21354503

8. Nassif A, Bensussan A, Boumsell L, Deniaud A, Moslehi H, Wolkenstein $\mathrm{P}$, et al. Toxic epidermal necrolysis: Effector cells are drug-specific cytotoxic T cells. J Allergy Clin Immunol 2004;114(5):1209-15. https://doi.org/10.1016/j.jaci.2004.07.047 PMid:15536433

9. Nassif A, Bensussan A, Dorothée G, Mami-Chouaib F, Bachot $N$, Bagot $M$, et al. Drug specific cytotoxic T-cells in the skin lesions of a patient with toxic epidermal necrolysis. J Invest Dermatol 2002;118(4):728-33. https://doi.org/10.1046/ j.1523-1747.2002.01622.x

PMid:11918724

10. Man CB, Kwan P, Baum L, Yu E, Lau KM, Cheng AS, et al. Association between HLA-B*1502 allele and antiepileptic drug-induced cutaneous reactions in Han Chinese. Epilepsia 2007;48(5):1015-8. https://doi.org/10.1111/ j.1528-1167.2007.01022.x PMid: 17509004

11. Nguyen DV, Chu HC, Nguyen DV, Phan MH, Craig T, Baumgart $\mathrm{K}$, et al. HLA-B*1502 and carbamazepine-induced severe cutaneous adverse drug reactions in Vietnamese. Asia Pac Allergy 2015;5:68-77. https://doi.org/10.5415/ apallergy.2015.5.2.68

PMid:25938071

12. Yang CW, Hung SI, Juo CG, Lin YP, Fang WH, Lu IH, et al. HLA$B^{*} 1502$-bound peptides: Implications for the pathogenesis of carbamazepine-induced Stevens-Johnson syndrome. J Allergy Clin Immunol 2007;120(4):870-7. https://doi.org/10.1016/j. jaci.2007.06.017

PMid:17697703

13. Hung SI, Chung WH, Liou LB, Chu CC, Lin M, Huang HP, et al. HLA-B*5801 allele as a genetic marker for severe cutaneous adverse reactions caused by allopurinol. Proc
Natl Acad Sci U S A 2005;102(11):4134-9. https://doi. org/10.3410/f.1088014.540977

PMid: 15743917

14. Chung WH, Chang WC, Stocker SL, Juo CG, Graham GG, Lee $\mathrm{MH}$, et al. Insights into the poor prognosis of allopurinolinduced severe cutaneous adverse reactions: The impact of renal insufficiency, high plasma levels of oxypurinol and granulysin. Ann Rheum Dis 2015;74(12):2157-64. https://doi. org/10.1136/annrheumdis-2014-205577

\section{PMid:25115449}

15. Fricke-Galindo I, LLerena A, López-López M. An update on HLA alleles associated with adverse drug reactions. Drug Metab Pers Ther 2017;32(2):73-87. https://doi.org/10.1515/ dmpt-2016-0025

PMid:28315856

16. Mounzer K, Hsu R, Fusco JS, Brunet L, Henegar CE, Vannappagari $V$, et al. HLA-B*57:01 screening and hypersensitivity reaction to abacavir between 1999 and 2016 in the OPERA $®$ observational database: A cohort study. AIDS Res Ther 2019;16(1):1. https://doi.org/10.1186/s12981-019-0217-3 PMid:30651100

17. Martínez Buitrago E, Oñate JM, García-Goez JF, Álvarez J, Lenis W, Sañudo LM, et al. HLA-B*57:01 allele prevalence in treatment-Naïve HIV-infected patients from Colombia. BMC Infect Dis 2019;19(1):793. https://doi.org/10.1186/ s12879-019-4415-3

PMid:31500584

18. Chung WH, Hung SI, Yang JY, Su SC, Huang SP, Wei CY, et al. Granulysin is a key mediator for disseminated keratinocyte death in Stevens-Johnson syndrome and toxic epidermal necrolysis. Nat Med 2008;14(12):1343-50. https://doi.org/10.1038/nm.1884 PMid: 19029983

19. Krensky AM, Clayberger C. Biology and clinical relevance of granulysin. Tissue Antigens 2009;73(3):193-8. https://doi. org/10.1111/j.1399-0039.2008.01218.x

PMid:19254247

20. Abe R, Yoshioka N, Murata J, Fujita Y, Shimizu H. Granulysin as a marker for early diagnosis of the Stevens-Johnson syndrome. Ann Intern Med 2009;151(7):514-5. https://doi. org/10.7326/0003-4819-151-7-200910060-00016 PMid:19805776

21. Fujita $Y$, Yoshioka N, Abe R, Murata J, Hoshina D, Mae $H$, et al. Rapid immunochromatographic test for serum granulysin is useful for the prediction of Stevens-Johnson syndrome and toxic epidermal necrolysis. J Am Acad Dermatol 2011;65(1):658. https://doi.org/10.1016/j.jaad.2010.04.042 PMid:21507517

22. Auquier-Dunant A, Mockenhaupt M, Naldi L. Correlations between clinical patterns and causes of erythema multiforme major, Stevens-Johnson syndrome, and toxic epidermal necrolysis: Result of an international prospective study. Arch Dermatol 2002;138:1019-24. https://doi.org/10.1001/ archderm.138.8.1019

PMid: 12164739

23. Morsy H, Taha EA, Nigm DA, Shahin R, Youssef EM. Serum IL-17 in patients with erythema multiforme or StevensJohnson syndrome/toxic epidermal necrolysis drug reaction, and correlation with disease severity. Clin Exp Dermatol. 2017;42(8):868-73. https://doi.org/10.1111/ced.13213 PMid:28940568

24. Iwai $S$, Sueki $H$, Watanabe $H$, Sasaki $Y$, Suzuki T, lijima M. Distinguishing between erythema multiforme major and Stevens-Johnson syndrome/toxic epidermal necrolysis immunopathologically. J Dermatol. 2012;39(9):781-6. https:// doi.org/10.1111/j.1346-8138.2012.01532.x 


\section{PMid:22458564}

25. Cho YT, Lin JW, Chen YC, Chang $\mathrm{CY}$, Hsiao $\mathrm{CH}$, Chung $\mathrm{WH}$ et al. Generalized bullous fixed drug eruption is distinct from Stevens-Johnson syndrome/toxic epidermal necrolysis by immunohistopathological features. J Am Acad Dermatol. 2014;70(3):539-48. https://doi.org/10.1016/j.jaad.2013.11.015

26. Valeyrie-Allanore L, Wolkenstein P, Brochard L, Ortonne N, Maître B, Revuz J, et al. Open trial of ciclosporin treatment for Stevens-Johnson syndrome and toxic epidermal necrolysis. $\mathrm{Br} J$ Dermatol 2010;163(4):847-53. https://doi org/10.1111/j.1365-2133.2010.09863.x PMid:20500799

27. Bastuji-Garin S, Fouchard N, Bertocchi M, Roujeau JC, Revuz J, Wolkenstein P. SCORTEN: A severity-of-illness score for toxic epidermal necrolysis. J Invest Dermatol 2000;115(2):149-53. https://doi.org/10.1046/j.1523-1747.2000.00061

PMid:10951229

28. Peña SV, Hanson DA, Carr BA, Goralski TJ, Krensky AM. Processing, subcellular localization, and function of 519 (granulysin), a human late $\mathrm{T}$ cell activation molecule with homology to small, lytic, granule proteins. J Immunol 1997;158(6):2680-8

PMid:9058801

29. Stenger S, Hanson DA, Teitelbaum R, Dewan P, Niazi KR Froelich $\mathrm{CJ}$, et al. An antimicrobial activity of cytolytic T cells mediated by granulysin. Science 1998;282(5386):121-5. https:// doi.org/10.1126/science.282.5386.121

PMid:9756476

30. Chung WH, Hung SI. Genetic markers and danger signals in Stevens-Johnson syndrome and toxic epidermal necrolysis. Allergol Int J Jpn Soc Allergol 2010;59(4):325-32. https://doi. org/10.2332/allergolint.10-rai-0261

PMid:20962567

31. Chung WH, Hung SI, Hong HS, Hsih MS, Yang LS, Ho HC, et al Medical genetics: A marker for Stevens-Johnson syndrome. Nature 2004;428(6982):486

PMid:15057820

32. Akkurt ZM, Uçmak D, Türkcü G, Yüksel H, Yildiz K, Arıca M. Expression of interleukin-17 in lesions of erythema multiforme may indicate a role for $\mathrm{T}$ helper 17 cells. Cent-Eur J Immunol 2014;39(3):370-6. https://doi.org/10.5114/ceji.2014.45950 PMid:26155150

33. Ogawa K, Takamori Y, Suzuki K, Nagasawa M, Takano S, Kasahara $Y$, et al. Granulysin in human serum as a marker of cell-mediated immunity. Eur J Immunol 2003;33(7):1925-33. https://doi.org/10.1002/eji.200323977
PMid:12884856

34. Lin J, Huang Y, Zhang L, Tang W, Li X, Wang X, et al. Evaluation of serum granulysin as a potential biomarker for nasopharyngeal carcinoma. Clin Chim Acta Int J Clin Chem 2016;454:72-6. https://doi.org/10.1016/j.cca.2015.12.035 PMid:26751807

35. Thuong PH, Tam DB, Sakurada S, Le Hang NT, Hijikata M, Hong LT, et al. Circulating granulysin levels in healthcare workers and latent tuberculosis infection estimated using interferon-gamma release assays. BMC Infect Dis 2016;16:580. https://doi.org/10.1186/s12879-016-1911-6 PMid:27756230

36. Su SC, Mockenhaupt M, Wolkenstein P, Dunant A, Le Gouvello S, Chen CB, et al. Interleukin-15 is associated with severity and mortality in Stevens-Johnson syndrome/toxic epidermal necrolysis. J Invest Dermatol 2017;137(5):1065-73. https://doi.org/10.1016/j.jid.2016.11.034 PMid:28011147

37. Saigusa $S$, Ichikura $T$, Tsujimoto $H$, Sugasawa $H$, Majima $T$, Kawarabayashi $\mathrm{N}$, et al. Serum granulysin level as a novel prognostic marker in patients with gastric carcinoma. J Gastroenterol Hepatol 2007;22(8):1322-7. https://doi. org/10.1111/j.1440-1746.2006.04796.x PMid:17688669

38. Nagasawa M, Isoda T, Itoh S, Kajiwara M, Morio T, Shimizu N et al. Analysis of serum granulysin in patients with hematopoietic stem-cell transplantation: Its usefulness as a marker of graftversus-host reaction. Am J Hematol 2006;81(5):340-8. https:// doi.org/10.1002/ajh.20570

PMid:16628730

39. Saito N, Abe R, Yoshioka N, Murata J, Fujita Y, Shimizu H. Prolonged elevation of serum granulysin in drug-induced hypersensitivity syndrome. Br J Dermatol 2012;167(2):452-3. https://doi.org/10.1111/j.1365-2133.2012.10921.x PMid:22384988

40. Posadas SJ, Padial A, Torres MJ, Mayorga C, Leyva L, Sanchez $E$, et al. Delayed reactions to drugs show levels of perforin, granzyme $B$, and Fas- $L$ to be related to disease severity. J Allergy Clin Immunol 2002;109(1):155-61. https://doi. org/10.1067/mai.2002.120563

\section{PMid:11799383}

41. Saito N, Qiao H, Yanagi T, Shinkuma S, Nishimura K, Suto A et al. An annexin A1-FPR1 interaction contributes to necroptosis of keratinocytes in severe cutaneous adverse drug reactions. Sci Transl Med 2014;6(245):245ra95. https://doi.org/10.1126/ scitransImed.3008227

PMid:25031270 